\title{
Diversification of Income Sources and their Significance in the Risk Management of Farms
}

\author{
Danuta Zawadzka, Agnieszka Kurdyś-Kujawska*
}

\begin{abstract}
The aim of this study is to identify the relationship between the diversification of income sources in Middle Pomerania farms and selected features describing the farms and farmers. The survey examined farms in the region of Central Pomerania. The research tool used was a questionnaire. The stated research problem was solved using the method of analysis and critique of the literature, the basic methods of the statistical analysis and multiple correspondence analysis. The study has shown that the diversification of income sources is the solution used by smaller-area farms, which are unrelated to the market and are rarely exposed to the occurrence of adverse events that may have a significant impact on the operation of the farm.
\end{abstract}

Keywords: income of farms, diversification, risk

\section{Introduction}

Agricultural production is exposed to a number of risks, the occurrence of which can cause a variety of negative consequences that affect the outcome of the business. Weather conditions, diseases of plants or animals, volatility of prices, rules and restrictions on the use of plant protection products (Managing agricultural... 2005) cannot be controlled by the farmer, but they have a direct impact on the level of a farm's income and the stability of the agricultural holding.

Risk management is aimed at risk reduction in all decision-making processes of the entity and the optimal protection against its negative effects (Kaczmarek 2010: 128-129). M.A. Jerzak describes risk management in agriculture in Poland as the anticipation of potential losses, and the accumulation of capital, which could compensate for these losses when they occur (Jerzak 2006: 115).

Actions taken by farmers to hedge against the risk may be either active or passive. Active measures manifest themselves in taking specific actions, through which it is possible to control the risk actively and purposefully (Hardaker et al. 1997: 12). The results of these activities are improved financial results and providing conditions so that the entity does not incur

\footnotetext{
* dr hab. Danuta Zawadzka prof. PK, Politechnika Koszalińska, Wydział Nauk Ekonomicznych, ul. Kwiatkowskiego 6e, 75-343, e-mail: danutaz@man.koszalin.pl, dr Agnieszka Kurdyś-Kujawska, Politechnika Koszalińska, Wydział Nauk Ekonomicznych, ul. Kwiatkowskiego 6e,75-343, e-mail: agakurdys@op.pl.
} 
losses greater than the unavoidable (Sobiech, Kurdyś-Kujawska 2014: 314). Passive measures mean the absence of any attempts to reduce the impact of risk (Halamczuk 2009: 19), usually associated with the creation of specific financial reserves that allow losses by the owners of the farm.

Undertaking specific actions to mitigate the risk or protection against its consequences depend on the attitude of farmers towards risk, on available resources, the financial situation of the farm, the organization of local and national markets, the stage in the life cycle of the farm's manager (Fleisher 1990), the size of the loss and the incidence of its occurrence and the possibility of the involvement of the state in the process of preventing or eliminating the risk (Anton 2011).

\section{The importance of diversifying sources of income in risk management}

The problem, described in the literature, of undertaking additional economic activity by farmers is determined in two ways. On the one hand, additional activities on a farm is a manifestation of the multi-skilling of farmers who undertake gainful activity outside of work on the farm or do business without using the resources of the farm. On the other hand, the additional economic activity means the diversification of the farm (Krakowiak-Bal 2010: 89-90; Wieruszewska 2006: 49; Podstawy strategii... 2003: 83), defined as the diversification of the structure of agricultural production and the use of resources such as land, capital and labor on farms to perform activities other than farming (Majewski, Radzikowska 2006). The combination of different sources of income (from the farm and non-farm) can help to increase the level and stability of income of (Czynniki i możliwości... 2013: 103), and the degree of financial independence (Woźniak 2008: 18; Hoogeveen 2001: 105-121) of the farm.

The diversification of income sources is classified as a risk management method in agriculture (Makki 2002; Grudziński 2008: 71; Śmiglak-Krajewska 2014: 140). According to experts in the field of insurance and farm management, what is of paramount importance among the risk management strategies available to farmers, is, among others, diversification of income sources (Guba, Majewski 2008), which constitutes an active form of self-protection against risk. It is the concept of ex-ante risk management (Barrett et al. 2001: 315-331). The acquisition of income from different sources allows mitigation and a reduction of the risk level of agricultural activity and leads to improved ability to cope in case of the occurrence of the negative effects of adverse events. Undertaking additional economic activity reduces the dependence on agricultural sources of income and increases the likelihood of maintaining agricultural activity. The benefits of diversification manifest in reducing the risk of losses, due to the fact that the decrease in income from a single source may be offset by the proceeds from other sources (Tyran 2010: 202; Bringham, Gapenski 2000: 51). A study by A. Kochar shows that by engaging in several types of business and increasing the income, small, medium and large farms are able to compensate for respectively $45 \%, 62 \%$ and $41 \%$ of low income due to losses in crops (Kochar 1995: 159-164). 
The main motive for farmers to work outside a farm is income risk (Jette-Nantel et al. 2011: 3), which is an outcome of the different risk categories that affect the size of agricultural income. The spectrum of risks that affect the income of farm owners is quite wide, among them we can distinguish two dominant threats: market (price) risk resulting from changes in external economic conditions of production and natural risks closely related the nature of agricultural production. Market risk can be reflected in the lack of opportunities to sell or purchase mass produced goods within a specified period, as well as the necessity of accepting prices, which do not always provide the profitability of production (Sobiech, Kurdyś-Kujawska 2014: 312). In contrast, natural risks may be reflected in inadequate supply - famine, or oversupply - high crop yield. It raises uncertainty about the volume of production, its costs and losses (Jerzak 2009: 16).

Increased exposure of farms to risk, resulting from the nature of agricultural production is a factor in diversifying sources of income on farms, but according to P. Hazell et al. diversification in terms of gainful employment outside the farm is an action sufficient in the case of small losses, even if they occur often, but it is not sufficient for a risk which is rare and is associated with a greater loss (Aidoo et al. 2014: 342 after Hazell et al. 1986).

\section{Material and research methods}

The aim of the study is to identify the relationship between the diversification of income sources in the Middle Pomerania farms and selected features describing the farms and farmers. The survey examined farms in the Central Pomerania region. Data were collected from people in charge or managing the farms at the end of May-June 2012. The research tool used was a questionnaire. The samples for the research were chosen in a non-random fashion, called snowball sampling. The stated research problem was solved using the method of analysis and critique of the literature, the basic methods of statistical analysis and multiple correspondence analysis, in which case the testing algorithm proceeded according to the following steps':

1. Designation of the Burt matrix to obtain a symmetric matrix block which, apart from the main diagonal of the matrix, contain contingency tables, corresponding to two different characteristics, comprising a number of objects with fixed terms of these two characteristics. On the main diagonal there are diagonal matrices in which the non-zero values represent the number of occurrences of a given categories features.

2. Determining the real dimension of the space of coexistence of categories of variables $\mathrm{K}$, according to the following formula

\footnotetext{
${ }^{1}$ The essence of this method lies in the fact that initially chosen numerically small group of respondents is tested and each member of the group determines (recommends) other members belonging to the population (Szreder 2004: 60).

${ }^{2}$ A detailed description of the method can be found in the works of Gatnar, Walesiak (2004): 285-315; Machowska-Szewczyk, Sompolska-Rzechuła (2010: 9-21; Sompolska-Rzechuła (2010): 53-64; Stanimir (2005).
} 


$$
K=\sum_{q=1}^{Q}\left(J_{q}-1\right)
$$

where:

$J_{q}$ - the number of categories of characteristics $q(q=1,2, \ldots, Q)$,

$Q$ - number of characteristics.

3. Checking the extent to which the eigenvalues of space with lower dimension explain the total inertia. The Greenacre criterion was used, according to which inertias significant to the study are those with principal inertias greater than $1 / Q$,

4. making modifications to the eigenvalues according to the following formula:

where:

$$
\tilde{\lambda}_{k}=\left(\frac{Q}{Q-1}\right)^{2} \cdot\left(\sqrt{\lambda_{k}}-\frac{1}{Q}\right)^{2},
$$

$Q$ - the number of features,

$\lambda_{k}-k$-the eigenvalue.

5. Using Ward's method for classification of the feature categories (Ward 1963: 236244):

In order to indicate the relationship between diversification of income sources and selected features describing the farm (farm status, number of employees, resources, agricultural land, soil class, the occurrence of damage on the farm, farm exposure to certain risks covered by insurance, the type of production) and the farmers (age, education, possession of a successor, the period of farm management), in the case of qualitative features there were appropriate categories introduced. The role of the dependent variable was served by one of the thirteen variants of features relating to the sources of income of the farm. In the study, the following variables and their categories were assumed:

1. DOCH - the source of income (1 - agricultural business only, 2 - from agricultural and non-agricultural business),

2. $\mathrm{ST}$ - status ( $\mathrm{t}$ - commodity farming, $\mathrm{n}$ - subsistence farming),

3. WIEK - age $(<=45$ - lower than 45 years, $>45$ - more than 45 years, 45 years - average in the group),

4. WYK - education (SW - secondary or higher education, PZ - primary or vocational education),

5. ZATR - the number of people employed permanently on the farm $(<=2-$ at most 2 people, $>2$ - more than 2 people, 2 - median),

6. NAST. - a successor on the farm $(\mathrm{T}-$ yes, $\mathrm{N}-\mathrm{no})$,

7. KIER - period of self-management of the farm $(<=16$ - no longer than 16 years, $>16$ - longer than 16 years, 16 - COG average), 
8. ZAS - land resources on the farm in ha $(<=15$ - smaller than 15 ha, $>15$ - larger than 15 hectares, 15 - median),

9. GLE - class of soils on the farm (1-4 - the dominant classes are $1-4$, remaining - the remaining classes of soil dominate),

10. SZK - the occurrence of injury ( $\mathrm{T}-$ yes, $\mathrm{N}-\mathrm{no})$,

11. RYZ - the level of exposure of the farm to risk $(>=2-$ more than $2,<2-$ less than $2,2-$ median $)^{3}$,

12. UBEZ - insurance for crops or livestock ( $\mathrm{T}-$ yes, $\mathrm{N}-$ no),

13. PR_MIESZ - mixed production ( $\mathrm{T}-$ yes, $\mathrm{N}-\mathrm{no})$.

The first feature "DOCH - a source of income" was considered a dependent variable and the next as independent. Testing the relationship between the categories of the first variable considered dependent, and the features of the twelve selected categories resulted in the Burt matrix with dimensions $26 \times 26$. The extent of the real space of the coexistence of answers was 13. It was also examined how the eigenvalue of space with a lower dimension explain the total inertia. Table 1 shows the eigenvalues and singular values and the degree of explanation of the total inertia.

\section{Table 1}

Singular values and eigenvalues and the degree of explanation of the total inertia

\begin{tabular}{llllc}
\hline \multirow{2}{*}{$\begin{array}{l}\text { Number } \\
\text { of dimensions } K\end{array}$} & \multicolumn{3}{c}{ Values } & \multicolumn{3}{c}{ Percent } \\
\cline { 2 - 5 } & singular $\gamma_{k}$ & eigenvalues $\lambda_{k}$ & inertia $\lambda_{k} / \lambda$ & cumulative $\tau_{k}$ \\
\hline 1 & 0.4341 & 0.1884 & 18.8417 & 18.8417 \\
2 & 0.3381 & 0.1143 & 11.4328 & 30.2744 \\
3 & 0.3055 & 0.0933 & 9.3325 & 39.6069 \\
4 & 0.3017 & 0.0910 & 9.0995 & 48.7064 \\
5 & 0.2965 & $\mathbf{0 . 0 8 7 9}$ & 8.7900 & 57.4964 \\
6 & 0.2649 & 0.0702 & 7.0160 & 64.5124 \\
7 & 0.2613 & 0.0683 & 6.8274 & 71.3397 \\
8 & 0.2478 & 0.0614 & 6.1410 & 77.4808 \\
9 & 0.2411 & 0.0581 & 5.8115 & 83.2923 \\
10 & 0.2179 & 0.0475 & 4.7483 & 88.0405 \\
11 & 0.2147 & 0.0461 & 4.6111 & 92.6516 \\
12 & 0.2040 & 0.0416 & 4.1623 & 96.8139 \\
13 & 0.1785 & 0.0319 & 3.1861 & 100.0000 \\
\hline
\end{tabular}

Source: own calculations.

The optimal size of the projection of space of the categories of the variables, according to Greenacre's criterion, was chosen and based on the condition: $\lambda_{k}>1 / Q$. In the present

\footnotetext{
${ }^{3}$ The respondent could assess farm exposure to the risk on a scale of 1 to 5 , where 1 meant a low degree, and 5 meant a high degree of exposure.
} 
case, the value $1 / Q=1 / 13=0.0769$ indicates the space $\mathrm{R} 5$. In order to determine the number of eigenvalues, which indicate the coordinates relevant to the projection on the space of the lower dimension, the "elbow" criterion was used (Fig. 1).

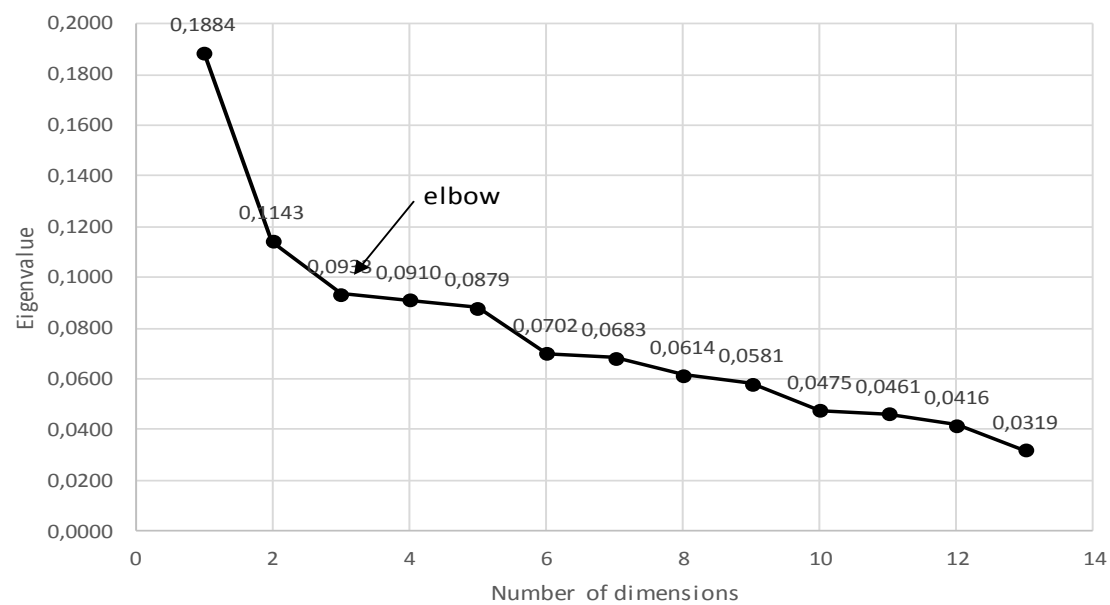

Figure 1. Diagram of the eigenvalues

Source: own calculations.

Modification of the eigenvalues using Greenacre's proposal (Table. 2).

\section{Table 2}

Modified singular values and eigenvalues and the degree of explanation of the total inertia

\begin{tabular}{llllc}
\hline \multirow{2}{*}{$\begin{array}{l}\text { Number } \\
\text { of dimensions } K\end{array}$} & Values & \multicolumn{3}{c}{ Percent } \\
\cline { 2 - 5 } & singular $\widetilde{\gamma}_{k}$ & eigenvalues $\widetilde{\lambda}_{k}$ & inertia $\widetilde{\lambda}_{k} / \tilde{\lambda}$ & cumulative $\widetilde{\tau}_{k}$ \\
\hline 1 & 0.3869 & 0.1497 & 36.7874 & 36.7874 \\
2 & 0.2830 & 0.0801 & 19.6768 & 56.4642 \\
3 & 0.2476 & 0.0613 & 15.0674 & 71.5316 \\
4 & 0.2435 & 0.0593 & 14.5657 & 86.0974 \\
5 & 0.2379 & 0.0566 & 13.9026 & 100.0000 \\
\hline \multicolumn{5}{c}{}
\end{tabular}

Source: own calcucations.

After modifying the eigenvalues, a presentation of feature categories co-occurrence will be presented in $R 3$, in which the degree of explanation of inertia is more than $71 \%$; the "scree" plot also indicates $R 3$. 


\section{Diversification of income sources in Middle Pomerania farms}

The owners of farms, apart from income from the work on their own farm, may produce income from agricultural production or self-employment, from the company operated as part of the farm, from working outside their farm - income from private activities of self-employment (a company outside the farm) or employment (full-time or casual employment in agriculture and agriculture outside their holdings), from the active or passive participation in the informal economy, from legal or illegal emigration and budget transfers (pensions, retirement benefits, pensions, social security, etc.) (Polska wieś po integracji... 2004: 160$161)$.

Income derived from agricultural activities was the main source of income for 155 farmers from the region of Central Pomerania (62.24\%). Gainful activity conducted outside the primary agricultural production was, next to agricultural activity, an active means of gaining income for farmers. In contrast, wage labor outside the farm, where one of the spouses worked, was the most important source of income for 60 farmers (24.09\%). The least important sources of income were non-profit sources (Table 3).

\section{Table 3}

The structure of the sources of income for farmers in Central Pomerania

\begin{tabular}{|c|c|c|c|}
\hline \multirow{3}{*}{ Specification } & \multicolumn{3}{|c|}{ The level of importance } \\
\hline & 1 & 2 & 3 \\
\hline & \multicolumn{3}{|c|}{ number of responses } \\
\hline Agriculturalactivity & $\begin{array}{l}155 \\
(62.25 \%)\end{array}$ & $\begin{array}{l}65 \\
(46.43 \%)\end{array}$ & $\begin{array}{l}1 \\
(3.33 \%)\end{array}$ \\
\hline Wage labor outside the farm & $\begin{array}{l}60 \\
(24.10 \%)\end{array}$ & $\begin{array}{l}34 \\
(24.29 \%)\end{array}$ & $\begin{array}{l}0 \\
(0.00 \%)\end{array}$ \\
\hline Non-agriculturaleconomicactivities & $\begin{array}{l}34 \\
(13.65 \%)\end{array}$ & $\begin{array}{l}33 \\
(23.57 \%)\end{array}$ & $\begin{array}{l}7 \\
(23.33 \%)\end{array}$ \\
\hline Non-profit sources & $\begin{array}{l}0 \\
(0.00 \%)\end{array}$ & $\begin{array}{l}8 \\
(5.71 \%)\end{array}$ & $\begin{array}{l}22 \\
(73.33 \%)\end{array}$ \\
\hline Number of responses & 249 & 140 & 30 \\
\hline
\end{tabular}

Respondents could indicate a maximum of 3 replies, numbering them in order of importance, 1 - main source of income.

Source: own.

The analysis using Ward's method indicates the emergence of three clusters of categories of variables related to the diversification of income sources in the Middle Pomerania farms. The first cluster reflects the strongest link between diversifying sources of income to the categories of farm characteristics, and indicates that diversifying sources of income depends on the surface of the farm and its relationship with the market, whether damage occurred in the past, and the insurance of crops and livestock. In the analyzed group of farms, engaging in additional activities to diversify income sources was typical for farms with an area of less than 15 ha of agricultural land, which produce primarily for their own 
consumption, and only a small proportion of their output is directed to market. The owners of these farms also reported no damage in the recent period which could jeopardize income stabilization and the functioning of the farm. In addition, a category of features can be distinguished which are in a weaker association with the category defining the diversification of income sources on farms. This class includes the following categories of analyzed characteristics: age and education of the person in charge of the farm, having a successor and the years of self-management of the farm. Diversification of income was associated with higher levels of education and the age of the farmer - less than 45 years old, which was connected to the period of self-management of the farm (no longer than 16 years). It follows that the education of farmers and their young age provides the necessary skills that enable them to participate in more profitable activities such as non-agricultural wage labor or self-employment. The third group of categories - the least related to the diversification of income sources in the Middle Pomerania farms, relates to farms which permanently employ at most two people, where poor and the poorest soils dominate, which, from the point of view of economic profitability, agricultural production is limited and those characterized by a low degree of exposure to particular risks (eg. drought, flood, frost, etc.). The managers of these farms have not used other methods to reduce the risk such as diversification of agricultural production and transferring the risk to another party (the insurance company).

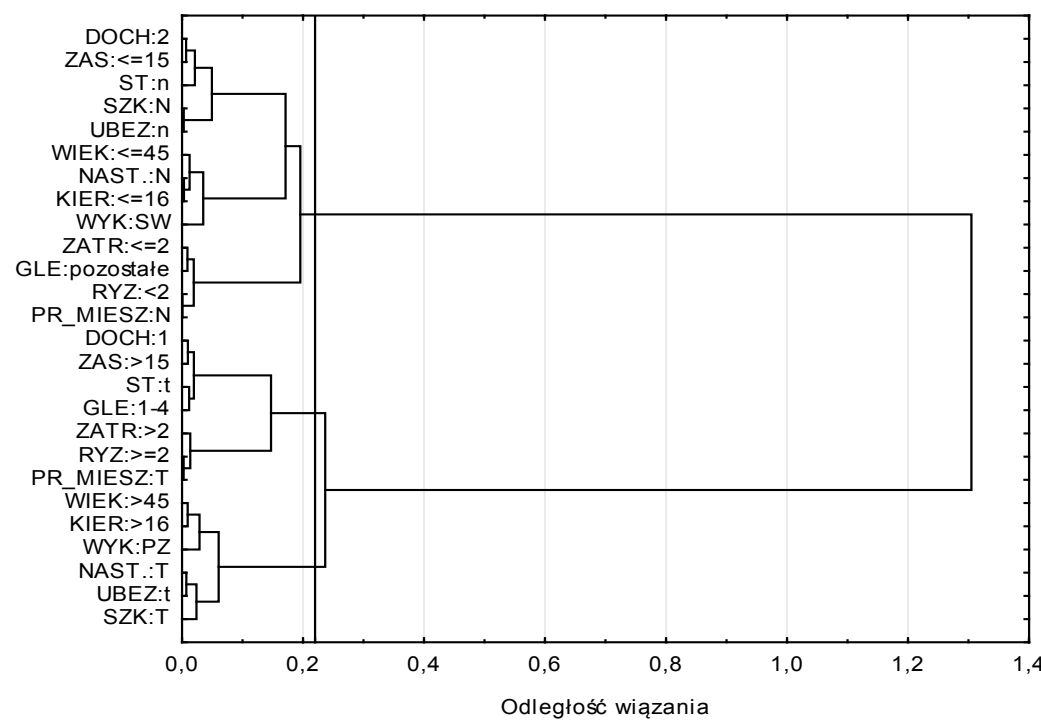

Figure 2. Dendrogram of the division of feature categories using Ward's method

Source: own. 


\section{Conclusions}

Based on the performed study, it can be stated that the diversification of income sources is the solution used by smaller-area farms, which are unrelated to the market and are rarely exposed to the occurrence of adverse events that may have a significant impact on the operation of the farm. Diversifying sources of income and thus decoupling farm income from the sale of production means that these farms are not using other tools (product diversification and insurance), which may limit the effects of certain risks.

\section{References}

Aidoo R., Mensah J.O., Wie P., Awunyo-vitor D. (2014), Prospects of crop insurance as a risk management tool among arable crop farmers in Ghanha, "Asian Economic and Financial Review" vol. 4 (3).

Anton J., Risk Management in CAP Reform: Policy Insight from OECD Studies (presentation), Seminar on "Risk management under the reformed CAP", Warsaw 2011.

Barrett C.B., Reardon T., Webb P. (2001), Nonfarm income diversification and household livelihood strategies in rural Africa: concepts, dynamics, and policy implications, "Food Policy" vol. 26.

Czynniki i możliwości ograniczania ryzyka w produkcji roślinnej poprzez ubezpieczenia (2013), ed. A. Wicka, Wydawnictwo SGGW, Warszawa.

Fleisher B. (1990), Agricultural risk management, Rienner Publishers London: Lynne.

Gatnar E., Walesiak M. (2004), Metody statystycznej analizy wielowymiarowej $w$ badaniach marketingowych, Wydawnictwo Akademii Ekonomicznej we Wrocławiu, Wrocław.

Grudziński J. (2008), Informatyczne narzędzia zarządzania ryzykiem w rolnictwie, „Inżynieria rolnicza” no. 11 (109).

Guba W., Majewski E. (2008), Priorities for eastern EU agriculture from an income stabilization point of view, in: Income stabilization in a changing agricultural Word: policy and tools, eds. E. Berg, R. Huirne, E. Majewski, M. Meuwissen, Warszawa.

Halamczuk M. (2009), Analiza, prognozowanie i zarządzanie ryzykiem cenowym na podstawowych rynkach rolnych - możliwości stabilizowania dochodów producentów rolnych. Synteza wyników badań prowadzonych w latach 2008-2009, IERiGŻ, Warszawa.

Hardaker J.B., Huirne R.B.M., Anderson J.R. (1997), Coping with risk in agriculture, CAB International, Oxon, United Kingdom.

Hoogeveen J.G.M. (2001), Income Risk, Consumption Security and the Poor, Oxford Develepment Stdies vol. 30 (1).

Jerzak M.A. (2006), Podstawowe zagadnienia ryzyka $w$ gospodarce rolnej, in: Ekonomiczne uwarunkowania wykorzystania rynkowych narzędzi stabilizacji cen i zarządzania ryzykiem $w$ rolnictwie, eds. M.A. Jerzak, A. Czyżewski, Akademia Rolnicza w Poznaniu, Poznań.

Jerzak M.A. (2009), Zarządzanie ryzykiem cenowym jako czynnik poprawy konkurencyjności gospodarstw rolnych w warunkach liberalizacji Wspólnej Polityki Rolnej UE, "Zagadnienia Ekonomiki Rolnej” nr 1 (318).

Jette-Nantel S., Freshwater D., Beaulieu M., Katchova A. (2011), Farm Income Variability and Off-Farm Diversification in Canadian Agriculture, Agriculture and Rural Working Paper Series no. 93, November.

Kaczmarek T.T. (2010), Zarządzanie ryzykiem. Ujęcie interdyscyplinarne, Difin, Warszawa.

Kochar A. (1995), Explaining Household Vulnerability to Idiosyncratic Income Shocks, "American Economic Review" vol. 85 , no. 2 .

Krakowiak-Bal A. (2010), Rozwój dodatkowej działalności gospodarczej w gospodarstwach rolnych $w$ UE, "Inżynieria Rolnicza" nr 5 (123).

Machowska-Szewczyk M., Sompolska-Rzechuła A. (2010), Analiza korespondencji w badaniu postaw osób dokonujących zakupów przez Internet, Ekonometria 29, Prace Naukowe Uniwersytetu Ekonomicznego we Wrocławiu, nr 141, Wrocław.

Majewski D., Radzikowska E. (2006), Znaczenie działań dywersyfikacyjnych dla polskiego rolnictwa, in: Różnicowanie produkcji rolniczej ze szczególnym uwzględnieniem obszarów o trudnych warunkach rolniczych oraz unikatowych walorach przyrodniczych, FAPA, Warszawa. 
Makki S.S. (2002), Crop insurance in the United States: Basic issues, performance, and lessons for developing countries, Presentation at the Inter-American Development Bank in Washington.

Managing agricultural production risk; Innovation in developing countries (2005), Agricultural and Rural development Department - World Bank.

Podstawy strategii zintegrowanego rozwoju rolnictwa i obszarów wiejskich w Polsce (2003), ed. J. Wiklin, Uniwersytet Warszawski, Warszawa.

Polska wieś po integracji z Unia Europejska (2004), Fundacja na Rzecz Rozwoju polskiego Rolnictwa, Warszawa.

Śmiglak-Krajewska M. (2014), Sposoby ograniczania ryzyka w gospodarstwach rolnych z terenu województwa kujawsko-pomorskiego, Roczniki Naukowe Ekonomii Rolnictwa i Rozwoju Obszarów Wiejskich vol. 101, nr 4.

Sobiech J., Kurdyś-Kujawska A. (2014), Ryzyko działalności rolniczej na obszarze Pomorza Środkowego i jego wplyw na podejmowane przez rolników decyzje finansowe $i$ inwestycyjne, in: Wzrost $i$ alokacja aktywów finansowych i rzeczowych rolników (przedsiębiorstw rolniczych i gospodarstw domowych, eds. D. Zawadzka, J. Sobiech, Politechnika Koszalińska, Koszalin.

Sompolska-Rzechuła A. (2010), Zastosowanie metody analizy zgodności w badaniu jakości życia kobiet, "Wiadomości Statystyczne" nr 1.

Stanimir A. (2005), Analiza korespondencji jako narzędzie do badania zjawisk ekonomicznych, Wydawnictwo Akademii Ekonomicznej we Wrocławiu, Wrocław.

Szreder M. (2004), Metody i techniki sondażowych badań opinii, PWE, Warszawa.

Tyran E. (2010), Dywersyfikacja jako proces dostosowawczy gospodarstw województwa małopolskiego, Rocznik Nauk Rolniczych, SERIA G, vol. 97, nr 4.

Ward J.H. (1963), Hierarchical grouping to optimize an objective function, "Journal of the American Statistical Association" vol. 58.

Wieruszewska M. (2006), Refleksja naukowa o wsi w perspektywie zmieniajacych sie podstaw teoretycznych, in: Wieś i rolnictwo w badaniach społeczno-ekonomicznych, ed. M. Kozakiewicz, IRWiR PAN, Warszawa.

Woźniak M. (2008), Dywersyfikacja szansa rozwoju indywidualnych gospodarstw rolnych w globalnej gospodarce, Zeszyty Naukowe SGGW no 67.

\section{DYWERSYFIKACJA ŹRÓDEL DOCHODÓW I JEJ ZNACZENIE W ZARZĄDZANIU RYZYKIEM W GOSPODARSTWACH ROLNYCH}

Streszczenie: Celem badań jest identyfikacja powiązań między dywersyfikacją źródeł dochodów w gospodarstwach rolnych Pomorza Środkowego, a wybranymi cechami opisującymi gospodarstwa rolne i rolników. Badaniu poddane zostały gospodarstwa rolne z regionu Pomorza Środkowego. Narzędziem badawczym był kwestionariusz ankiety. Postawiony problem badawczy został rozwiązany z wykorzystaniem metody analizy i krytyki piśmiennictwa, podstawowych metod analizy statystycznej oraz wielowymiarowej analizy korespondencji. Badania wykazały, iż dywersyfikacja źródeł dochodów jest rozwiązaniem wykorzystywanym przez mniejsze obszarowo gospodarstwa rolne, niepowiązane z rynkiem, które w niewielkim stopniu narażone są na występowanie niekorzystnych zdarzeń, mogących w istotny sposób wpłynąć na funkcjonowanie gospodarstwa rolnego.

Słowa kluczowe: dochody gospodarstw rolnych, dywersyfikacja, ryzyko

\section{Citation}

Zawadzka D., Kurdyś-Kujawska A. (2015), Diversification of Income Sources and their Significance in the Risk Management of Farms, Zeszyty Naukowe Uniwersytetu Szczecińskiego nr 855, „Finanse, Rynki Finansowe, Ubezpieczenia" nr 74, t. 1, Wydawnictwo Naukowe Uniwersytetu Szczecińskiego, Szczecin, s. 619-628; www. wneiz.pl/frfu. 